\title{
Implementation of School and Community Relationship Techniques (A Case Study in SDN Karangbesuki 2 Malang, Indonesia)
}

\author{
Neris Eka Agustina \\ Educational Administration Department \\ Universitas Negeri Malang \\ Malang, Indonesia \\ raden.bambang.fip@um.ac.ic
}

\author{
Raden Bambang Sumarsono \\ Educational Administration Department \\ Universitas Negeri Malang \\ Malang, Indonesia \\ raden.bambang.fip@um.ac.id
}

\author{
Imam Gunawan \\ Educational Administration Department \\ Universitas Negeri Malang \\ Malang, Indonesia \\ imam.gunawan.fip@um.ac.id
}

\begin{abstract}
This study aims to describe the application of techniques for establishing school and community relations. This research method is a qualitative, phenomenological approach, through a case study design at SDN Karangbesuki 2 Malang. Data collection was carried out using in-depth interview techniques, participant observation, and documentation studies. To obtain research results using a single case analysis technique. Checking the validity of the data using triangulation, checking members, observing persistence, and the adequacy of reference materials. The results of the study are, the techniques used in establishing relationships with the community are the technique of group meetings, faceto-face techniques, correspondence, reports to parents, uniforms, and home visits.
\end{abstract}

Keywords - implementation, relationship techniques, school, community

\section{INTRODUCTION}

Elementary School (SD) is the most basic level of education and as the main foundation or foundation that needs serious attention, meaning to get a higher quality of education, it must begin with the creation and formation of quality elementary schools. This is in accordance with the opinion expressed by Bafadal that quality schools are elementary schools that are able to function as a forum for the educational process, a place of socialization process, and a process of transformation, so as to be able to deliver students to be educated, have knowledge and technology, including the nation's culture that makes it ready to enter the next school, namely junior high school [1].

The continuation of the implementation of education programs in primary schools is certainly a shared responsibility between schools, families, and the community. The three components are equally liable for the smooth implementation of education. Imron \& Sumarsono stated that children learn and develop in the family, school and community environment. This implies that at the level of the family environment, the obligation of parents (in which the role of father and mother) is to educate their children in family life [2]. The school environment with a distinctive structure and institutional system as a nursery for the nation's children are also obliged to educate and teach their students. The surrounding community environment with all its dynamics and characteristics that can directly or indirectly influence the development of students as members of the community. This means signaling that, parents and the community has a shared responsibility to be involved in the implementation of education in schools in order to achieve maximum educational goals.

The existence of the community is certainly needed by educational institutions and vice versa, both need each other. Without assistance from the community an educational institution cannot function properly and without a good program, an educational institution will fail to achieve its goals. The community also needs educational institutions to facilitate academic and non-academic development in order to achieve the objectives of the national education system. Rugaiyah stated that creating a quality school is a process that requires strong commitment and cooperation from all school stakeholders [3]. From this opinion, it is very clear, that in order to realize quality education it is necessary to support the involvement or participation of the community. Meanwhile, Wiyono explained, that the process of implementing education in schools will be able to succeed optimally if supported by several parties, both resources from schools, parents, and the community [4].

The relationship between school and society is needed for the development of education in order to achieve quality. Thus, it can be said that the quality of education will not succeed optimally, without the support of the community. The Law of the Republic of Indonesia Number 20 of 2003 concerning the National Education System states several roles that can be carried out by the community in implementing education, as stipulated in Article 54 Paragraphs (1) and (2), which read: (1) community participation in education includes the participation of individuals, groups, families, professional organizations, entrepreneurs, and community organizations in the implementation and quality control of educational services; and (2) the community can participate as resource persons, implementers, and users of educational outcomes. From the foundation of the law, it is very clear the importance of the relationship between school and society [5].

With the establishment of a harmonious relationship between school and community, the purpose of education will be realized. Wolf's research results (in the Ministry of National Education, 2007) confirms that there is a very significant correlation $(0.80)$ between the family environment and children's learning achievement [6]. In this connection Herman \& Yeh state that there is a positive relationship between student achievement and parental satisfaction with school [7]. This provides evidence that the pattern of collaboration between families (parents) is very influential in achieving school quality. 
The results of the research by Hewison \& Tizard show that there is a relationship between the involvement of parents and the achievement of reading outcomes of students in school [8]. Meanwhile, the results of Preedy's research show that parents' involvement in school activities has a positive effect on the progress and development of student learning [9]. Castro, et.al. through the results of the study revealed that parental involvement leads to children's academic achievement in school [10]. Given the effective implementation of school relations with the community, this will have an impact on improving the quality of schools, as expressed by Sumarsono et.al. that students' academic and non-academic achievements will increase when there is involvement from parents [11]. Therefore, in empowering the community for the implementation of education programs in schools it is necessary to apply techniques to establish community relations effectively.

Based on a study of the results of the study, researchers are interested in conducting further research on the application of techniques to establish school relationships with the community. The object in this research is at SDN Karangbesuki 2 Malang. This school is one of the primary schools located in the outskirts of Malang City but has various academic and non-academic achievements. In addition, the elementary school has applied the techniques of public relations well, with an indicator of the level of community participation that is enthusiastic.

\section{METHOD}

Researchers strive to develop in-depth knowledge of the object under study, namely the technique of establishing relationships with the community in an effort to improve the quality of schools so that the nature of research is more explorative and descriptive. For that reason, researchers used qualitative research methods, phenomenological approaches, with case study designs. The researcher adopted the opinion of Miles, Huberman, and Saldana that the case as a phenomenon of some sort is occurring and a bounded context [12]. Whereas Yin states an empirical inquiry case study that investigates a contemporary phenomenon within its real-life context, especially when the boundaries between phenomenon and context are not clearly evident [13]. Based on the design of the research carried out, the presence of researchers is very necessary because researchers act as key instruments in extracting information in depth and detail.

This research was conducted at SDN Karangbesuki 2 Malang City. Sources of data in this study using primary and secondary data. Primary data was obtained through a series of interviews with school principals, class teachers, parents, school committee, and parent associations in the class are often called "paguyuban kelas". Meanwhile, secondary data is obtained through documentation and observation studies which are then analyzed and used as supporting evidence.

Data collection procedures in this study used three techniques, namely in-depth interviews, participant observation, and documentation studies. The interview technique is carried out by researchers by searching for key information sources, then traced to other informants in order to obtain accurate data. Meanwhile, the documentation study used as the research data is related to the implementation of school activities that involve the community, and other supporting data that is well documented by the school. So that through documentation studies, researchers get facts or data related to the techniques of implementing school and community relations. While observing activities, researchers conducted a series of observations on several school activities involving the community, for example when the school carried out the acceptance of student learning outcomes where parents were invited to school. From these activities, researchers also get facts or data about the implementation of reporting techniques to parents. From these data collection techniques, valid research data is obtained.

To analyze the data, researchers used a single case analysis technique through three stages, namely reduction, display, and verification (conclusion) data. These stages are used to select and filter information that is in accordance with the research focus so that it can be concluded according to the information obtained. Data checking is needed to ensure the truth of the information obtained by researchers. Checking the validity of this research data includes three activities, namely, triangulation, member checking, observation persistence, and the adequacy of reference material

\section{RESULT AND DISCUSSION}

Based on data analysis, the results of the study showed that the technique of establishing relationships with the community conducted by SDN Karangbesuki 2 Malang, namely 1) group meeting techniques, 2) face-to-face techniques, 3) correspondence, 4) reports to parents, 5) uniforms and 6) home visits. Forms of application of group meeting techniques are through parents' meetings, school committee meetings, class meetings, socialization of school education and program policies, parenting day activities, and celebrations for the graduation of sixth graders (purna wiyata bhakti). Meanwhile, for the application of face-to-face techniques, that is, parents of students personally and individually, face to face directly with the headmaster or class teacher, the wider community (business world/industry) discuss cooperation agreements with the school. This is in line with the thoughts of Imron \& Sumarsono that group meeting techniques can be in the form of seminars, workshops, symposiums, meetings, discussions, and meetings [2]. Furthermore, Imron \& Sumarsono stated that face-to-face techniques are done between school visits with parents of students or the community individually rather than classical [2].

The technique of establishing relationships with the community is also done through correspondence, in this case, the school sends letters to parents of students and the community. Mailing to parents is done when the school invites parents to come to school for the purpose of discussing school programs, acceptance of student learning outcomes, and other needs. Meanwhile, for sending letters to the public, it is widely exemplified when schools offer cooperation for the implementation of school activities. With regard to this technique Benty \& Gunawan state that correspondence has been carried out by every educational institution, in addition to relatively inexpensive fees, this technique is considered capable of being carried out by every educational institution [14].

Parent report techniques are implemented in the form of schools providing reports to parents about children's learning outcomes, providing reports to the community on the implementation of school activities involving the 
community. Benty and Gunawan reports to parents are interpreted as reports on their children's learning progress at school [14]. Meanwhile, Imron and Sumarsono stated that reports to parents were interpreted as conveying information from teachers to parents about the progress of children's activities at school [2].

School uniform attributes are used as one form of the school culture which is a characteristic of SDN Karangbesuki 2 in Malang City and that distinguishes this school from other schools. This is intended to provide information to the community on the identity of the school through uniforms so that the community will get to know the school through uniforms worn by students. This technique is one of the most effective techniques to introduce schools to the community. Furthermore, the technique of home visit activities was done by the way the teachers of SD Karangbesuki 2 Malang visited the parents' homes to provide information about the progress of children's learning in school and also the problems faced by children when studying in school. This is in line with the statement of Imron and Sumarsono that through home visits, the teacher will know the problem of the child at home [2]. If every child is known to have problems in totality, then the education program will be easier to plan to suit his interests.

\section{CONCLUSION}

Based on the results of the study concluded that the technique of establishing relationships with the community conducted by SDN Karangbesuki 2 Malang City are: 1) group meeting techniques, application of group meeting techniques, namely through parents' meetings, school committee meetings, class community meetings, socialization of education policies and programs schools, parenting day activities, and celebrations for graduation of sixth graders (purna wiyata bhakti); 2) face-to-face techniques, the form of the application of this technique is the parents of students personally and individually face to face to face with the principal or class teacher, the community at large (the business world/industry world) discuss cooperation agreements with the school; 3) correspondence techniques, this technique is carried out by way of schools sending letters to parents of students or the community in general who intend to invite them to come to school or other information notices; 4) report techniques to parents, schools provide reports to parents about children's learning outcomes, provide reports to the community on the implementation of school activities involving the community; 5) uniform clothing, this technique is carried out to provide information to the public on school identity through uniforms so that the community will get to know the school through uniforms worn by students; and 6) home visit technique, the implementation of this technique is done by the way the teacher visits the parents' home to provide information about the progress of children's learning in school and also the problems faced by children when studying in school.

\section{REFERENCES}

[1] I. Bafadal.. Peningkatan profesionalisme guru sekolah dasar dalam kerangka manajemen peningkatan mutu berbasis sekolah. Bumi Aksara, 2003

[2] A. Imron \& R.B. Sumarsono. Manajemen Hubungan dan Partisipasi Masyarakat di Sekolah. Malang: Penerbit dan Percetakan UM, 2017.

[3] Rugaiyah. Pengembangan Komptensi Kepala Sekolah dalam Meningkatkan Mutu Pendidikan. Artikel dalam Prosiding International Conference Educational Management, Administration and Leadership. Malang: Jurusan Administrasi Pendidikan, 2012.

[4] B. B. Wiyono. Partisipasi Masyarakat terhadap Pelaksanaan Kegiatan Pendidikan. Manajemen Pendidikan Volume 23, Nomor 1, Maret 2010, (10-11).

[5] Undang-Undang, R. I. No. 20 tahun 2003 tentang Sistem Pendidikan Nasional. Bandung: Citra Umbara, 2003.

[6] Depertemen Pendidikan Nasional. Pendidikan dan Pelatihan: Manajemen Hubungan Masyarakat dalam Pemberdayaan Masyarakat. Jakarta: Ditnaga Ditjen PMPTK, 2007.

[7] J. L. Herman \& J. P. Yeh. Some Effective of Parent Involvement in School. 1983. Urban Review 15 (1): 11-16.

[8] J. Hewison, \& J. Tizard. Parental involvement and reading attainment. British Journal of Educational Psychology, 1980, 50(3), 209-215.

[9] M. Preedy. (Ed). Managing The Effective School. London: The Open University, 1993.

[10] Castro, M., Casas, E., Martin, E., Lizasoain, L., Asencio, E., \& Gaviria, J. Parental Involvement on Student Academic Achievemnt: A Meta-Analysis. Education Research Review, 2015, 14, 33-46.

[11] R. B. Sumarsono, A. Imron, B. B.Wiyono, \& I. Arifin. Parents' Participation in Improving the Quality of Elementary School in the City of Malang, East Java, Indonesia. International Education Studies, 2016, 9(10), 256.

[12] M. B.Miles, A. Huberman, \& J. Saldana. Qualitative data analysis: A methods sourcebook. 3rd. Sage, 2014.

[13] RK Yin. Case Study Research: Design and Methods. First edition. Sage Publications, Thousand Oaks CA, 2003.

[14] D.D.N Benty \& I.Gunawan, Manajemen Hubungan Sekolah Dan Masyarakat.Malang: Universitas Negeri Malang, 2015. 